\title{
OPTIMALISASI PEMUPUKAN DI LAHAN GAMBUT
}

\author{
Elfi Yenny Yusuf ${ }^{1}$, Marlina², Mulono Apriyanto ${ }^{3}$ \\ 1,2Prodi Agroteknologi, Fakultas Pertanian, Universitas Islam Indragiri, Tembilahan \\ ${ }^{3}$ Prodi Teknologi Pangan, Fakultas Pertanian, Universitas Islam Indragiri, Tembilahan \\ Email: mulonoapriyanto71@gmail.com (korespondensi)
}

\begin{abstract}
Increasing the productivity of peatlands can be done by applying the right fertilization system. The purpose of this study was to determine the appropriate dose of NPK fertilization in intercropping red chili and shallots on peat soil. This research was conducted at the Laboratory and Experimental Garden of the Faculty of Agriculture, Indragiri Islamic University. The study took place from August to December 2020. The study was carried out using a Completely Randomized Design (CRD) with 3 replications. , N2 (500 kg/ha), N3 (750 kg/ha) in red chilies and shallots. The results showed that treatment with a dose of $500 \mathrm{~kg} / \mathrm{h}$ a of NPK fertilizer in an intercropping system of chili with shallots on peat soil gave the best growth and yield of shallots. Treatment dose of $250 \mathrm{~kg} / \mathrm{ha}$ NPK fertilizer gave the best red chili fruit production.
\end{abstract}

Keywords: NPK Fertilizer, Peat, Intercropping

\begin{abstract}
Abstrak
Peningkatan produktivitas lahan gambut dapat dilakukan dengan menerapkan sistem pemupukan yang tepat. Tujuan penelitian ini adalah untuk menentukan dosis pemupukan NPK yang tepat pada tumpangsari cabai merah dan bawang merah di tanah gambut. Penelitian ini dilaksanakan di Laboraturium dan Kebun Percobaan Fakultas Pertanian, Universitas Islam Indragiri. Penelitian berlangsung daribulan Agustus hingga Desember 2020. Penelitian dilaksanakan dengan menggunakan Rancangan Acak Lengkap (RAL) dengan 3 ulangan. Perlakuan dalam penelitian ini dosis pupuk NPK 16:16:16 yaitu NO (O kg/ha), N1 (250 kg/ha), N2 (500 kg/ha), N3 (750 kg/ha) pada cabai merah dan bawang merah. Hasil penelitian menunjukkan bahwa perlakuan dosis pupuk NPK $500 \mathrm{~kg} / \mathrm{ha}$ dalam system tumpangsari cabai dengan bawang merah di tanah gambut memberikan pertumbuhan dan hasil tanaman bawang merah terbaik. Perlakuan dosis pupuk NPK $250 \mathrm{~kg} / \mathrm{ha}$ mememberikan produksi buah tanaman cabai merah terbaik.
\end{abstract}

Kata kunci: Pupuk NPK, Gambut, Tumpang Sari

\section{PENDAhUluan}

Berdasarkan beberapa hasil penelitian, produksi tanaman sayuran yang dibudidayakan di lahan gambut masih rendah. Penerapan sistem tumpang sari (intercropping) diharapkan dapat meningkatkan produktivitas lahan gambut [1]. Sistem tumpangsari adalah sistem tanam yang terdapat dua atau lebih jenis tanaman yang berbeda ditanam secara bersamaan pada waktu yang sama atau berbeda dengan jarak tanam teratur pada sebidang tanah yang sama[2].

Namun yang menjadi permasalahan dalam sistem tumpangsari adalah kompetisi antar tanaman yang dibudidayakan misalnya terhadap unsur hara, air, nutrisi, cahaya dan ruang tumbuh yang lebih tinggi dari pada monokultur.

\section{TINJAUAN PUSTAKA}

\subsection{Lahan Gambut}

Lahan gambut merupakan lahan yang berasal dari bentukan gambut beserta vegetasi yang terdapat di atasnya, terbentuk didaerah yang topografinya rendah, bercurah hujan tinggi atau didaerah yang suhunya sangat rendah. Tanah gambut mempunyaikandungan bahan organik yang tinggi (>12\% C/karbon) dan kedalamangambut minimum $50 \mathrm{~cm}$. Tanah gambut diklasifikasikan sebagai Histosol yang mengandung bahan organik lebih dari 30 persen dengan ketebalan $40 \mathrm{~cm}$ atau lebih, di bagian 80 $\mathrm{cm}$ teratas profil tanah[3], [4]. Sebagai sumberdaya alam, gambut memiliki kegunaan untuk budidaya tanaman pertanian maupun kehutanan, sebagai aquakultur, dapat digunakan 
sebagai bahan bakar, media pembibitan, ameliorasi tanah,dan untuk menyerap zat pencemar lingkungan[2]. Gambut dengan sifatsifat fisika dan kimia tanah yang khas, tergenang, pada kondisi alamiah, dan sangat berbeda dengan sifat tanah mineral. Berdasarkan ketebalan lapisan gambut, gambut terbagi dalam lapisan dangkal dengan tebal lapisan $<50 \mathrm{~cm}$, sedang dengan tebal lapisan $50-100 \mathrm{~cm}$, dan gambut dalam dengan tebal lapisan $>200 \mathrm{~cm}$ [5].

\subsubsection{Potensi Lahan Gambut untuk Sayuran}

Lahan rawa gambut yang sesuai, potensial untuk tanaman pangan semusim (annual crops) adalah gambut dangkal (0,5-1 m) sampai sedang (1-2 $\mathrm{m})$ yang terletak pada bagian pinggiran kubah. Pada lahan gambut, sistem usahatani terpadu yang cocok dikembangkan adalah sistem usahatani berbasis tanaman pangan dan komoditas andalan. Pengelolaan lahan gambut dengan sistem usahatani berbasis tanaman palawija dan hortikultura dapat dikelola dan dikembangkan dengan menggunakan teknologi budidaya, pengelolaan air, peningkatan kesuburan, dan pembuatan saluran drainase. Dalam pengelolaan dan pengembangannya tetap menjamin kelestarian sumberdaya alam.

Komoditas pertanian yang dapat diusahakan di lahan gambut antara lain adalah tanaman pangan (padi, jagung, sorgum, ubi kayu, ubi jalar, talas, tanaman palawija, dan sayuran (kedelai, kacang tanah, kacang tunggak, terung, mentimun, kacang panjang, cabai), tanaman buah-buahan, nenas, pisang, nangka, jeruk, rambutan, mangga, petai, jengkol, dan jambu mete.

\subsection{Pemupukan di Lahan Gambut}

Pemeliharaan pertanaman tidak dapat dilepaskan dari pemberian pupuk. Pupuk adalah bahan yang mengandung satu atau lebih unsur hara baik organik atau anorganik yang ditambahkan pada media tanam atau tanaman untuk mencukupi kebutuhan hara yang diperlukan tanaman sehingga mampu berproduksi dengan baik. Pupuk berbeda dari suplemen. Pupuk mengandung bahan baku yang diperlukan pertumbuhan dan perkembangan tanaman, sementara suplemen seperti hormon tumbuhan membantu kelancaran proses metabolisme [2], [3], [6]. Pemupukan adalah tindakan memberikan tambahan unsur-unsur hara pada kompleks tanah, baik langsung maupun tidak langsung sehingga mampu menyumbangkan bahan makanan bagi tumbuhan/ tanaman. Pemupukan pada prinsipnya merupakan pemberian bahan penyedia hara guna menambah atau menggantikan hara yang telah digunakan atau hilang. Pemupukan akan memberikan manfaat bagi pertanaman jika memberikan nilai tambah hasil pada tanaman. Kemanfaatan pemupukan diukur dengan nilai efisiensi pupuk. Efisiensi pupuk adalah jumlah kenaikan hasil yang dapat dipanen atau parameter pertumbuhan lainnya yang diukur sebagai akibat pemberian satu satuan pokok atau hara.

Pemupukan yang efisien akan menghemat penggunaan pupuk, karena dengan jumlah pupuk yang lebih sedikit akan diperoleh hasil yang sama atau lebih tinggi.

\section{METODOLOGI PENELITIAN}

Penelitian ini dilaksanakan di Laboraturium dan Kebun Percobaan Fakultas Pertanian Universitas Islam Indragiri. Penelitian berlangsung dari bulan Agustus sampai Desember 2020. Bahan tanam yang digunakan dalam penelitian ini adalah benih bawang merah varietas Jawa Bima Brebes dan benih cabai merah varietas Lado F1.

Bahan lainnya seperti kompos, pupuk NPK, dolomite, insektisida, fungisida, furadan. Selain itu adapun alat yang digunakan dalam penelitian ini adalah cangkul, meteran, plat perlakuan, cat minyak, paku, handsprayer, gembor, kamera, dan alat-alat tulis. Penelitian ini menggunakan Rancangan Acak Lengkap (RAL) dengan 3 ulangan. Dosis pemupukan dalam penelitian adalah pupuk NPK 16:16:16 yaitu NO (0 kg/ha), N1 (250 kg/ha), N2 (500 kg/ha), N3 (750 kg/ha). Pengukuran $\mathrm{pH}$ awal dilakukan pada tanah gambut kemudian dilakukan pemberian dolomit dengan dosis 1 ton/ha dan pupuk kompos 15 ton/ha. Tanaman bawang merah ditanam 2 minggu sebelum penanaman cabai merah serta dilakukan pemupukan NPK dengan dosis 350 $\mathrm{kg} / \mathrm{ha}$. Bawang merah ditanam diantara tanaman cabai merah dengan jarak tanam $20 \mathrm{~cm} \times 20 \mathrm{~cm}$. Penyulaman dilakukan pada 1 MST.

Penanaman cabai dilakukan saat bibit berumur 3 minggu. Pemupukan NPK dilakukan 3 tahap, yaitu saat tanam, $21 \mathrm{HST}$, dan $50 \mathrm{HST}$ dengan masing-masing $1 / 3$ dosis setiap pemberian. Pemanenan bawang merah dilakukan pada umur 60 HST, dimana tanaman telah menunjukkan kriteria panen.

Parameter yang diamati pada tanaman bawah merah yaitu: tinggi tanaman, bobot basah per rumpun dan bobot kering per rumpun. Sedangkan parameter untuk tanaman cabai merah yaitu: tinggi tanaman, jumlah buah, dan bobot buah per tanaman. Data yang diperoleh dianalisis menggunakan analisis ragam (uji $\mathrm{F}$ ) pada taraf $5 \%$ dengan uji lanjut BNT. 


\section{HASIL DAN PEMBAHASAN}

\subsection{Pertumbuhan dan Produksi Tanaman}

\section{Tinggi Tanaman}

Hasil analisis sidik ragam menunjukkan bahwa pengaturan jarak tanam dan pupuk NPK berpengaruh nyata terhadap tinggi tanaman bawang merah. Pertumbuhan bawang merah tanpa pemupukan NPK nyata meningkatkan tinggi tanaman bawang merah pada sistem tumpangsari. Semakin lebar jarak tanam cabai yang digunakan dalam system tumpangsari cabai dengan bawang merah, maka tinggi tanaman cenderung menjadi lebih rendah. Hal ini diduga karena jarak tanam yang lebih lebar memiliki ruang terbuka antara tanaman yang lebih luas, sehingga menyebabkan tingginya evaporasi dan leaching unsur hara yang diberikan.

Pada tanah marginal dianjurkan menggunakan jarak tanam yang rapat dalam batas tertentu. Bawang merah ditanam 2 minggu lebih cepat dari cabai merah. Hal ini bertujuan untuk mengurangi persaingan antara tanaman dalam sistem tumpang sari dalam memperebutkan unsur hara, air, cahaya dan $\mathrm{O}_{2}$. Tinggi tanaman bawang merah dari hasil penelitian $(25.78-34.56 \mathrm{~cm})$ masih sesuai dari deskripsi tanaman bawang merah yaitu $25-44 \mathrm{~cm}$. Hal ini menunjukkan bahwa bawang varietas Bima Brebes mampu tumbuh dan beradaptasi pada tanah gambut. $\mathrm{Hal}$ ini sependapat dengan penelitian [7], [8] yang menyatakan bahwa tanaman bawang merah varietas Bima Brebes cukup adaptif terhadap tanah gambut.

\section{Jumlah umbi per rumpun}

Hasil analisis ragam menunjukkan bahwa perlakuan utama pupuk NPK memberikan pengaruh nyata terhadap jumlah umbi per rumpun tanaman bawang merah. Jumlah umbi per rumpun bawang merah nyata meningkat dengan perlakuan pupuk NPK dosis 250-750 kg/ha. Hal ini menunjukkan bahwa dengan pemberian pupuk NPK yang dilakukan pada tanaman cabai meningkatkan ketersediaan unsur hara pada tanah gambut. Ketersediaan unsur hara nitrogen, fosfor, kalium dan magnesium yang optimal bagi tanaman dapat meningkatkan pembentukan klorofil, meningkatkan aktifitas fotosintesis, sehingga menghasilkan fotosintat yang lebih banyak yang berhubungan dengan hasil umbi $[8],[9]$.

\subsection{Produksi Tanaman}

Pemupukan NPK lebih dari $250 \mathrm{~kg} / \mathrm{ha}$ tidak memberikan pengaruh nyata terhadap jumlah umbi per rumpun bawang merah pada system tumpangsari dengan cabai di tanah gambut. Hal ini menunjukkan bahwa dengan dosis NPK $250 \mathrm{~kg} / \mathrm{ha}$ pada system tumpangsari telah cukup untuk memenuhi kebutuhan tanaman bawang merah. Selain itu, pada penelitian ini semua plot mendapatkan pemupukan NPK dasar dengan dosis yang sama untuk tanaman bawang merah. Oleh karena itu, tanah gambut masih mengandung cukup hara dari pemupukan sebelumnya, sehingga peningkatan dosis pupuk NPK diatas $250 \mathrm{~kg} / \mathrm{ha}$ pada tanaman cabai tidak memberikan pengaruh nyata terhadap jumlah umbi per rumpun bawang merah [3], [10].

Tabel 1. Produksi tanaman cabai merah dan bawang merah di tanah gambut

\begin{tabular}{|l|c|c|c|c|}
\hline \multirow{2}{*}{ Tanaman Cabe } & \multicolumn{4}{|c|}{ Dosis Pupuk NPK } \\
\cline { 2 - 5 } & $\begin{array}{c}\text { No } \\
(0 \mathrm{~kg} / \mathrm{ha})\end{array}$ & $\begin{array}{c}\mathrm{N} 1 \\
(250 \mathrm{~kg} / \mathrm{ha})\end{array}$ & $\begin{array}{c}\mathrm{N} 2 \\
(500 \mathrm{~kg} / \mathrm{ha})\end{array}$ & $\begin{array}{c}\mathrm{N} 3 \\
(750 \mathrm{~kg} / \mathrm{ha})\end{array}$ \\
\hline Jumlah buah per tanaman & $4,03 \mathrm{de}$ & $5,20 \mathrm{bc}$ & $3,84 \mathrm{de}$ & $6,29 \mathrm{a}$ \\
\hline $\begin{array}{l}\text { Bobot buah per tanaman } \\
\text { (g) }\end{array}$ & $6,43 \mathrm{ef}$ & $8,57 \mathrm{a}-\mathrm{d}$ & $5,76 \mathrm{ef}$ & $9,75 \mathrm{a}$ \\
\hline Bobot per buah $(\mathrm{g})$ & $2,55 \mathrm{abc}$ & $2,71 \mathrm{a}$ & $2,25 \mathrm{bcd}$ & $2,25 \mathrm{bcd}$ \\
\hline
\end{tabular}

Angka-angka pada baris dan kolom yang diikuti huruf kecil yang sama menunjukan tidak berbeda nyata menurut uji BNT $(a=0.05)$

Hasil analisis ragam menunjukkan bahwa jarak tanam cabai dan pemberian pupuk NPK tidak berpengaruh nyata terhadap tinggi tanaman cabai merah. Menunjukkan bahwa memberikan tinggi tanaman yang cenderung sama pada setiap perlakuan. Hal ini diduga bahwa jarak tanam yang digunakan tidak terjadi kompetisi cahaya matahari dan unsur hara antara tanaman sejenis (cabai dengan cabai) maupun berbeda jenis (cabai dengan bawang) yang menyebabkan tinggi tanaman cabai cenderung sama. Hal ini didukung oleh pernyataan [1], [11] bahwa, pertumbuhan tanaman sangat di tentukan oleh intensitas, kualitas, dan lamanya penyinaran.

Tinggi tanaman cabai merah dari hasil penelitian (49.67-61.50 cm) jauh lebih rendah dari deskripsi yaitu 110-140 cm. Rendahnya pertumbuhan tanaman cabai berhubungan erat dengan kondisi lingkungan saat penelitian. Pada saat penelitian di lapangan musim kemarau sehingga tanaman 
cabai mudah terserang hama dan penyakit diantaranya adalah hama trips, kutu kebul dan kutu daun persik.

Tabel 2. Produksi tanaman bawang merah di tanah gambut

\begin{tabular}{|l|c|c|c|c|}
\hline \multicolumn{2}{|l|}{ Tanaman bawang merah } & \multicolumn{4}{|c|}{ Dosis Pupuk NPK } \\
\cline { 3 - 6 } & $\begin{array}{c}\text { No } \\
(0 \mathrm{~kg} / \mathrm{ha})\end{array}$ & $\begin{array}{c}\mathrm{N} 1 \\
(250 \mathrm{~kg} / \mathrm{ha})\end{array}$ & $\begin{array}{c}\mathrm{N} 2 \\
(500 \mathrm{~kg} / \mathrm{ha})\end{array}$ & $\begin{array}{c}\mathrm{N} 3 \\
(750 \mathrm{~kg} / \mathrm{ha})\end{array}$ \\
\hline $\begin{array}{l}\text { Berat umbi basah per } \\
\text { rumpun }(\mathrm{g})\end{array}$ & $22,37 \mathrm{~cd}$ & $23,84 \mathrm{c}$ & $22,47 \mathrm{c}$ & $34,59 \mathrm{a}$ \\
\hline $\begin{array}{l}\text { Berat umbi kering per } \\
\text { rumpun }(\mathrm{g})\end{array}$ & $17,82 \mathrm{~cd}$ & $17,82 \mathrm{~cd}$ & $17,65 \mathrm{~d}$ & $28,43 \mathrm{a}$ \\
\hline
\end{tabular}

Angka-angka pada baris dan kolom yang diikuti huruf kecil yang sama menunjukan tidak berbeda nyata menurut uji BNT $(a=0.05)$

Selain itu, rendahnya pertumbuhan tanaman cabai pada penelitian ini diduga karena varietas tersebut belum adaptif pada tanah masam (gambut). Pada tanah masam faktor mendasar yang mengakibatkan pertumbuhan tanaman terhambat (kerdil) yaitu keracunan alumunium. Kosentrasi Al tinggi pada tanah asam dapat menghambat pertumbuhan beberapa spesies [12]. Hasil analisis ragam menunjukkan bahwa bahwa jarak tanam cabai dan pemberian pupuk NPK berpengaruh nyata terhadap jumlah buah pertanaman, bobot buah pertanaman dan bobot per buah.

Hasil penelitian menunjukkan bahwa jumlah buah per tanaman dan bobot buah per tanaman cabai merah dalam sistem tumpangsari pada tanah gambut terlihat bahwa kombinasi perlakuan jarak tanam 60 $\mathrm{cm} \times 50 \mathrm{~cm}$ (J2N2) dengan dosis pupuk NPK $500 \mathrm{~kg} / \mathrm{ha}$ memberikan hasil yang sama baiknya dengan kombinasi perlakuan jarak tanam $70 \mathrm{~cm} \times 50 \mathrm{~cm}$ (J3N3) dengan dosis pupuk $750 \mathrm{~kg} / \mathrm{ha}$, serta perlakuan jarak tanam $50 \times 50 \mathrm{~cm}$ dengan dosis pupuk 250 $\mathrm{kg} / \mathrm{ha}$. Hal ini menunjukkan belum terjadinya persaingan dalam memanfaatkan ruang tumbuh terutama cahaya, sehingga jarak tanam yang lebih rapat dapat menghasilkan hasil tanaman yang relatif sama dengan jarak tanam yang lebih besar. Berdasarkan hal tersebut diduga ketersediaan unsur hara yang dibutuhkan oleh cabai merah tidak terganggu dengan keberadaan bawang merah di daerah perakarannya.

Pada penelitian ini, pengaturan jarak tanam yang lebih rapat $(50 \mathrm{~cm} \times 50 \mathrm{~cm}$ ) juga mampu menekan penggunaan pupuk NPK hingga 50\%. Hal ini juga sesuai dengan pernyataan [13] yang menyatakan bahwa dengan pemberian pupuk anorganik $1 / 4$ dosis anjuran dapat meningkatkan pertumbuhan cabai di tanah gambut.

Namun bila diamati pada bobot per buah cabai, perlakuan jarak tanam $60 \mathrm{cmx} 50 \mathrm{~cm}$ dengan dosis pupuk NPK $500 \mathrm{~kg} / \mathrm{ha}(2.00 \mathrm{~g})$ dan jarak tanam $70 \mathrm{~cm} \times 50 \mathrm{~cm}$ dengan dosis pupuk NPK $750 \mathrm{~kg} / \mathrm{ha}(2.40 \mathrm{~g})$ menghasilkan buah yang nyata lebih kecil dibandingkan perlakuan jarak tanam $50 \mathrm{~cm} \times 50 \mathrm{~cm}$ dengan dosis pupuk NPK $250 \mathrm{~kg} / \mathrm{ha}(2.79 \mathrm{~g})$. Hal ini menunjukkan bahwa perlakuan jarak tanam $50 \mathrm{~cm} \times 50 \mathrm{~cm}$ dengan dosis pupuk NPK 250 $\mathrm{kg} / \mathrm{ha}$ menghasilkan buah yang memiliki kualitas umbi yang lebih tinggi.

Berdasarkan bobot buah per tanaman, potensi produksi cabai tertinggi pada penelitian ini yaitu 3.84 ton/ha. Hasil tersebut masih lebih rendah dibandingkan dengan potensi hasil cabai varietas Lado F1. Rendahnya produksi cabai merah yang dihasilkan pada penelitian ini diduga karena varietas yang digunakan belum adaptif untuk dibudidayakan di tanah gambut.

[14] menyatakan komponen hasil seperti bobot per buah dan bobot buah total pertanaman merupakan karakter kuantitatif yang kompleks yang terekspresi secara fenotipe baik morfologi maupun fisiologi tanaman yang dipengaruhi oleh genetik dan lingkungan tempat tanaman tumbuh. Selain itu, dikarenakan penyakit keriting daun yang menyerang hingga $80 \%$ tanaman cabai, sehingga produksi yang didapatkan kehilangan hasil hingga $60 \%$. Sesuai dengan pernyataan [15] yang menyatakan bahwa virus kuning pada tanaman cabai dapat mengakibatkan kehilangan hasil $20-100 \%$.

\section{KESIMPULAN DAN SARAN}

Pertumbuhan bawang merah hasil terbaik diperolehpada kombinasi perlakuan jarak tanam rapat $(50 \mathrm{~cm} \times 50 \mathrm{~cm})$ dengan pupuk NPK dosis $500 \mathrm{~kg} / \mathrm{ha}$. Hasil terbaik diperoleh pada tanaman cabai dengan pupuk NPK dosis $250 \mathrm{~kg} / \mathrm{ha}$.

\section{DAFTAR PUSTAKA}

[1] M. Arpah, Marlina, and M. Apriyanto, "Effect Of Grant Palm Oil Ash To The 
Growth And Production Of Two Corn Varieties (Zea Mays L) In Peatland," Int. J. Sci. Technol. Res, vol. 9, no. 4, pp. 990-993, 2020.

[2] Marlina, I. Sari, E. Y. Yusuf, Y. Riono, and M. Apriyanto, "Utilization Of Industrial Waste Pulp And Palm Oil On Growth And Results Of Corn (Zea Mays L) On Peat," Int. J. Sci. Technol. Res, vol. 9, no. 1, pp. 109-112, 2020.

[3] $\mathrm{Y}$. Riono and $\mathrm{M}$. Apriyanto, "PEMANFAATAN ABU SEKAM PADI DALAM INOVASI PEMUPUKAN KACANG HIJAU (Vigna radiate L) DI LAHAN GAMBUT," Selodang Mayang J. IIm. Badan Perenc. Pembang. Drh. Kabupaten Indragiri Hilir, vol. 6, no. 2, p. 60, 2020, doi: 10.47521/selodangmayang.v6i2.164.

[4] Anonim, "Indragiri hilir," BPS, INHIL, 2013.

[5] S. H. Limin, "PEMANFAATAN LAHAN GAMBUT DAN PERMASALAHANNYA," 2006.

[6] Tedi Susilo; and M. Apriyanto, "Pengaruh Dua Hormon Pertumbuhan Dan Tiga Pupuk Kendang Formula Pada Varietas Papaya (Carica Papaya L.) Di Simpang Kiri, Kecamatan Pelangiran," J. Agro Indragiri, vol. 5, no. 1, pp. 6-11, 2020, doi: 10.32520/jai.v5i1.1451.

[7] M. Apriyanto and Yulianti, "Analisis Produksi dan Pemasaran Gula Merah di Desa Rumbai Jaya, Kecamatan Kempas, Kabupaten Indragiri Hilir," J. Teknol. Pertan., vol. 9, no. 1, pp. 26-29, 2020.

[8] M. Ramli and M. Apriyanto, "MANAJEMEN KEUANGAN UNTUK MENINGKATKAN PEREKONOMIAN KELUARGA DI MASA PANDEMI COVID-19," Sellodang Mayang, vol. 6, no. 3, pp. 145-152, 2020.

[9] M. Apriyanto, Monograf: PENINGKATAN
MUTU BIJI KAKAO PETANI. 2021.

[10] A. Azhar, K. N. S. Fikri, V. A. Siregar, and M. Apriyanto, "PENCEGAHAN, PEMBERANTASAN, PENYALAHGUNAAN DAN PEREDARAN GELAP NARKOBA (P4GN) pada PESANTREN," J. Inov. Penelit., vol. 1, no. 3, pp. 2463-2468, 2020.

[11] M. Apriyanto, Marlina, and M. Arpah, "Perbanyakan Tanaman Secara Vegetatif Di Desa Pekan Kamis Kelurahan Tembilahan Barat," Celeb. Abdimas J. Pengabdi. Kpd. Masy., vol. 2, no. 1, pp. 42-46, 2020.

[12] R. Baharuddin and S. Sutriana, "Pertumbuhan Dan Produksi Tanaman Tumpangsari Cabai Dengan Bawang Merah Melalui Pengaturan Jarak Tanam Dan Pemupukan Npk Pada Tanah Gambut," Din. Pertan., vol. 35, no. 3, pp. 73-80, 2020, doi: 10.25299/dp.2019.vol35(3).4567.

[13] Ahmad et al., "Student Responses During Online Learning in the Covid-19 Pandemic Period Student Responses During Online Learning in the Covid - 19 Pandemic Period," J. Phys. Conf. Ser., vol. 1764 , no. 1 , p. 012125,2021 , doi: 10.1088/1742-6596/1764/1/012125.

[14] A. Syahza, D. Bakce, M. Irianti, and B. Asmit, "Potential Development of Leading Commodities in Efforts to Accelerate Rural Economic Development in Coastal Areas Riau, Indonesia," J. Appl. Sci., vol. 20, no. 5, pp. 173-181, 2020, doi: 10.3923/jas.2020.173.181.

[15]M. Masganti, K. Anwar, and M. A. Susanti, "Potensi dan Pemanfaatan Lahan Gambut Dangkal untuk Pertanian," J. Sumberd. Lahan, vol. 11, no. 1 , p. $43=52$, 2020, doi: 10.21082/jsdl.v11n1.2017.43-52. 